\title{
Doxorubicin Loaded-UiO-66-NH2 Coated With Poly(N-Vinylcaprolactam) For Controlled Release of Doxorubicin Against A549 Lung Cancer
}

Navid Rakhshani

Islamic Azad University

nahid Hassanzadeh Nemati ( $\square$ nahid_hasanzadeh@yahoo.com )

Islamic Azad University Science and Research Branch https://orcid.org/0000-0003-1725-8430

Ahmad Ramazani Saadatabadi

Sharif University of Technology

S.K. Sadrnezhaad

Sharif University of Technology

\section{Research Article}

Keywords: Metal-organic framework, UiO-66-NH2, Poly(N-Vinylcaprolactam), Doxorubicin, Lung cancer

Posted Date: May 5th, 2021

DOl: https://doi.org/10.21203/rs.3.rs-483360/v1

License: (c) (i) This work is licensed under a Creative Commons Attribution 4.0 International License.

Read Full License 


\section{Abstract}

The use of nano metal-organic frameworks (NMOFs) has been developed for drug delivery systems due to their high porosity and large specific surface area. In this work, UiO-66- $\mathrm{NH}_{2} \mathrm{NMOFs}$ were synthesized via the microwave heating method and doxorubicin (DOX) molecules were incorporated into the UiO-66$\mathrm{NH}_{2}$ NMOFs. Then, poly(N-Vinylcaprolactam) (PNVCL) synthesized by the free radical polymerization was coated on the NMOFs surface to fabricate the $\mathrm{pH} /$ temperature-sensitive carrier against A549 lung cancer cells death in vitro. The synthesized nanocarriers were characterized using FTIR, XRD, SEM, FESEM, TGA, and BET analysis. The average particle sizes of UiO-66- $\mathrm{NH}_{2}$ MOF and PNVCL coated-UiO-66- $\mathrm{NH}_{2}$ /DOX MOF nanoparticles were found to be $175 \mathrm{~nm}$ and $235 \mathrm{~nm}$, respectively. TGA analysis showed that the PNVCL percentage coated on the UiO-66- $\mathrm{NH}_{2}$ NMOFs surface was about $17.5 \%$, and $27.3 \%$ for NMOFs incubated in $1 \%$ and $2 \%$ PNVCL solutions, respectively. The BET surface area of UiO-66- $\mathrm{NH}_{2} \mathrm{NMOFs,} \mathrm{UiO-}$ 66- $\mathrm{NH}_{2}$ NMOFs/DOX $100 \mu \mathrm{g} \mathrm{mL}^{-1}$, and PNVCL 1\% coated-NMOFs/DOX was found to be 1052,121 , and $87 \mathrm{~m}^{2} \mathrm{~g}^{-1}$, respectively. The DOX release data of UiO-66- $\mathrm{NH}_{2}$ and PNVCL coated- UiO-66- $\mathrm{NH}_{2} / \mathrm{DOX}$ were evaluated under $\mathrm{pH}$ values of $5.5,7.4$, and temperatures of $25^{\circ} \mathrm{C}, 37^{\circ} \mathrm{C}$. The anticancer activity of synthesized NMOFs was investigated against lung cancer cells (A549) in vitro. The maximum cytotoxicity of A549 cancer cells was found to be $76 \%$ using PNVCL $1 \%$ coated-UiO-66- $\mathrm{NH}_{2} / \mathrm{DOX} 100 \mu \mathrm{gL}^{-1} \mathrm{NMOFs}$.

\section{Introduction}

Metal-organic frameworks (MOFs) as crystalline porous materials have been widely used for targeted delivery of anticancer drugs due to their high specific surface area, large porosity, good biocompatibility, and fine pore sizes [1-7]. The nanosized-MOFs (NMOFs) prepared by the microwave heating method exhibited unique physic-chemical properties in comparison to the micrometer scale of MOFs $[1,8]$. The advantages of MOFs compared with other inorganic drug delivery systems (DDS) are the high encapsulation efficiency and their easier functionalization for targeted delivery [9-14]. UiO-66 MOFs ([Zr6O4(OH)4]) with high stability and high biocompatibility as well as good biodegradability and high specific surface area had a high potential for delivery of anticancer drugs [15-17]. Furthermore, UiO-66 MOFs with Zr-O clusters, and metal sites, as well as octahedral and tetrahedral cavities, could be considered for the controlled release of Doxorubicin (DOX) due to having a coordination interaction between the $\mathrm{Zr}$ (IV) clusters of UiO-66 and hydroxyl groups of DOX $[4,18]$. Moreover, the presence of open cavities and clusters in the UiO-66 MOFs matrix causes the incorporation of the high content of drug molecules, and following its release could occur in a controlled manner. UiO-66 MOF is also a good candidate for the controlled release of anticancer agents into the cancer tissues as a pH-sensitive carrier [18]. Thus, DOX could be released from UiO-66 MOFs into the acidic tumor sites due to the protonation of phosphate and weaknesses of the interaction between DOX and Zr-O clusters of UiO-66 MOF under acidic condition $[18,19]$. 
The accumulation of NMOFs in the bloodstream could be decreased by the coating of NMOFs surface with polymers which improve the stability of NMOFs and provide the effective application of NMOFs in DDSs of anticancer drugs during the in vitro and in vivo therapy of various cancers through the targeted delivery of anticancer agents into the tumor tissues [20-22]. Furthermore, the specific distribution of anticancer drugs on the cancerous cells could decrease the adverse side effects of anticancer drugs via decreasing the non-selective distribution of drugs on the healthy cells. The coating of stimuli-responsive polymers on the MOFs surface could result in the enhancement of the permeability of the anticancer drug on the cancerous cells [23-26].

The lower critical solubility temperature (LCST) thermoresponsive polymers such as poly (N-isopropyl acrylamide) (PNIPAAm), and poly (N-vinyl caprolactam) (PNVCL) have been developed for DDSs of anticancer drugs [27-30]. Among LCST polymers, PNVCL as a hydrophilic biocompatible temperaturesensitive polymer is used for various biomedical applications [30-34]. Furthermore, the biocompatibility of PNVCL is higher than PNIPAAm, due to the hydrolysis of acrylamide groups of PNIPAAm and the production of small compounds which is not suitable for biomedical applications [35]. The LCST of PNVCL is ranging from $\sim 32-34^{\circ}$ which is close to physiological temperature. Thus the release rate could be controlled by the coating of PNVCL on the MOF surface at body temperature through the delay in the release of anticancer agents.

In the present study, UiO-66- $\mathrm{NH}_{2}$ NMOFs were synthesized via the microwave heating method and DOX molecules were loaded into the NMOFs. Then, its surface was coated with PNVCL. The synthesized NMOF and PNVCL coated-nanoparticles were characterized using FTIR, XRD, SEM, FESEM, TGA, and BET analysis. The release profiles of DOX from UiO-66- $\mathrm{NH}_{2}$ and PNVCL coated UiO-66/DOX were studied under different $\mathrm{pH}$ values and temperatures. The anticancer activity of synthesized NMOFs was investigated against A549 lung cancer cells in vitro.

\section{Experimental}

\subsection{Materials}

2-amino terephthalic acid (BDC-NH2, purity $\geq 99.9 \%$ ), zirconium chloride ( $\mathrm{ZrCl} 4$, purity $\geq 99.9 \%$ ) supplied from Sigma-Aldrich (Germany) and N, N Dimethylformamide (DMF, purity $\geq 99.0 \%$ ), hydrochloric acid $(\mathrm{HCl}, 37 \%)$ purchased from Fluka (Switzerland) were used for the synthesis of UiO-66- $\mathrm{NH}_{2} \mathrm{MOF}$ nanoparticles. N-Vinylcaprolactam (NVCL), 2,20-Azoisobutyronitrile (AIBN), 3-mercaptopro-pionic acid (MPA), and diethyl ether provided from Sigma-Aldrich (Germany) were used for the synthesis of PNVCL.

\subsection{Synthesis of UiO-66- $\mathrm{NH}_{2}$ and UiO-66- $\mathrm{NH}_{2} / \mathrm{DOX}$}

UiO-66- $\mathrm{NH}_{2}$ NMOFs were synthesized via the microwave method as described in reference [5]. Briefly, $\mathrm{ZrCl}_{4}(125 \mathrm{mg})$ and $\mathrm{BDC}-\mathrm{NH}_{2}(134 \mathrm{mg})$ were dispersed into the $15 \mathrm{~mL} \mathrm{DMF}$ and $1 \mathrm{~mL} \mathrm{HCl}$ under sonication 
for $1 \mathrm{~h}$. Then, the mixture was transferred into the microwave and the heating proceeded at $130^{\circ} \mathrm{C}$ for $1 \mathrm{~h}$. Then, the product was washed with DMF and methanol three times and was dried at $60^{\circ} \mathrm{C}$ for $6 \mathrm{~h}$.

To load DOX molecules into the UiO-66- $\mathrm{NH}_{2}$ MOF, 5 mg of UiO-66- $\mathrm{NH}_{2}$ NMOFs were dispersed into DOX solutions $\left(10,50\right.$, and $\left.100 \mu \mathrm{g} \mathrm{mL}^{-1}\right)$ for $24 \mathrm{~h}$ under stirring. Then, the prepared UiO-66- $\mathrm{NH}_{2} / \mathrm{DOX}$ was washed with ethanol and distilled water three times. Then, the prepared products were centrifuged at $12000 \mathrm{rpm}$ for $20 \mathrm{~min}$. The final content of DOX in NMOFs samples was determined according to the initial content of DOX, the final content of DOX in solution, and DOX content in the supernatant after centrifugation of NMOFs using UV-Vis spectrophotometer at a wavelength of $481 \mathrm{~nm}$. The drug encapsulation DEE (\%) is evaluated as follows:

\section{DEE $(\%)=\frac{\text { Final content of drugs in samples }}{\text { Initial content of drugs in solution }} \times 100 \%$ (Eq. 1)}

\subsection{Synthesis of PNVCL and PNVCL coated- UiO-66- $\mathrm{NH}_{2} / \mathrm{DOX}$}

The carboxylated PNVCL is synthesized by free radical polymerization of NVCL, MPA, and AIBN in isopropanol at $70{ }^{\circ} \mathrm{C}$ for $8 \mathrm{~h}$. Then, diethyl ether was added to precipitate the synthesized product. Later, the precipitated product was dried under vacuum. The prepared sample was dispersed in deionized water and was dialyzed for 4 days (MWCO of 5000) to remove the unreacted materials. Finally, the obtained product was lyophilized.

To coat the UiO-66- $\mathrm{NH}_{2} / \mathrm{DOX}$ surface with PNVCL, the predetermined amount of MOF nanoparticles was dispersed in $1 \%$ and $2 \%$ PNVCL (dissolved in distilled water) under stirring for $24 \mathrm{~h}$ and then, centrifuged at $12000 \mathrm{rpm}$ for $39 \mathrm{~min}$ to remove the non-attached PNVCL on the MOFs surface. The prepared UiO-66$\mathrm{NH}_{2}$ /DOX/PNVCL samples were washed three times with deionized water and dialyzed for 3 days (MWCO of 12000 ) and then dried at $30^{\circ} \mathrm{C}$ for $24 \mathrm{~h}$. Finally, the obtained product was lyophilized for further investigations. The schematic of the PNVCL and PNVCL/UiO-66- $\mathrm{NH}_{2} / \mathrm{DOX}$ synthesis is illustrated in Fig.1.

\subsection{Characterization tests}

The X-ray diffraction (XRD) patterns were recorded using Philips X'pert diffractometer in the range of 10$80^{\circ}$ at $2 \theta$ with $\mathrm{Cu}-\mathrm{Ka}$ radiation. To analyze the functional groups of $\mathrm{UiO}-66-\mathrm{NH}_{2}, \mathrm{UiO}-66-\mathrm{NH}_{2} / \mathrm{DOX}, \mathrm{PNVCL}$, and UiO-66/DOX/PNVCL, the FTIR spectra of samples were conducted on an Equinox 55 FTIR spectrometer in the range of $4000-400 \mathrm{~cm}^{-1}$. The hydrodynamic diameter and size distribution of the UiO66 MOFs and DOX loaded-MOFs were determined using dynamic light scattering (DLS) by a Malvern Zetasizer Nano (Malvern Instruments, Worcestershire). The scanning electron microscopy (SEM, JEOL JSM-6380) and field emission scanning electron microscopy (FESEM, MIRA3TESCAN-XMU) were applied to compare the morphology and structure of UiO-66- $\mathrm{NH}_{2} / \mathrm{DOX}$ and PNVCL coated- UiO-66- $\mathrm{NH}_{2} / \mathrm{DOX}$ MOF 
nanoparticles. The thermal analysis of UiO-66- $\mathrm{NH}_{2} / \mathrm{DOX}$ and PNVCL coated- UiO-66- $\mathrm{NH}_{2} / \mathrm{DOX} \mathrm{MOF}$ nanoparticles was carried out using thermogravimetric analysis (TGA Q500) by the heating rate of $10{ }^{\circ} \mathrm{C}$ $\mathrm{min}^{-1}$ ranging from $50-700^{\circ} \mathrm{C}$. The Brunauer-Emmett- Teller (BET) method was used to measure the specific BET surface area of MOFs (Micromeritics ASAP 2010, Micromeritics, Norcross, GA, USA) by the N2 adsorption-desorption isotherm. The UV-Vis spectrophotometer (JAS.CO V-530, Japan) was used to measure the final concentration of DOX at a wavelength of $481 \mathrm{~nm}$.

\subsection{Drug release and kinetic studies}

To obtain the DOX release behavior from synthesized MOFs, the drug loaded-MOFs were incubated in 50 $\mathrm{mL}$ of $0.1 \mathrm{M}$ phosphate buffer solution at temperatures of $25,37^{\circ} \mathrm{C}$ and $\mathrm{pH}$ values of $5.5,7.4$. At predetermined time intervals, $2 \mathrm{~mL}$ of incubation solution was collected from the solution medium. While $2 \mathrm{~mL}$ of fresh PBS was simultaneously added into the dissolution medium. The DOX release was determined according to its concentration at a certain time and actual drug content in MOFs. The release experiments were carried out three times and the average values were reported. The kinetic data of DOX release were analyzed by the zero-order, Higuchi [36], and Korsmeyer-Peppas [37] pharmacokinetic models to obtain the drug release mechanism from synthesized MOFs.

\subsection{Cell viability}

To investigate the biocompatibility of MOFs samples, the synthesized nanoparticles were incubated in the L929 normal fibroblast cells (Institute Pasteur of Iran, IPI, Tehran, Iran) cultured in RPMI with $10 \%$ fetal calf serum and $1 \%$ penicillin-streptomycin at $37^{\circ} \mathrm{C}$ in a humidified atmosphere of $5 \% \mathrm{CO}$. The cell viability of synthesized DOX loaded-MOF nanoparticles $(100 \mu \mathrm{g} / \mathrm{mL})$ against A549 lung cancer cell lines (IPI, Tehran, Iran) was evaluated after 24, 48, and $72 \mathrm{~h}$ incubation time as described previously [38]. The ELISA microplate reader (Multiskan MK3, Thermo Electron Corporation, USA) at a wavelength of $570 \mathrm{~nm}$ was used to determine the cell viability of A549 cells treated with MOF nanoparticles. The CyFlow flow cytometer (Partec, Germany) by staining of cells with Annexin V-fluorescein isothiocyanate (VFITC) /propidium iodide ( $\mathrm{PI})$ was used to compare the apoptosis of A549 cancer cells in the presence of various MOFs samples [39].

\section{Results}

\subsection{Characterization of MOF nanoparticles}

The XRD patterns of UiO-66- $\mathrm{NH}_{2}$ MOF and PNVCL coated UiO-66- $\mathrm{NH}_{2} /$ DOX MOF nanoparticles are illustrated in Fig.2. The presence of sharp diffraction peaks at $2 \theta=7.5^{\circ}$ and $8.5^{\circ}$ corresponding to (111), and (002) planes indicated the formation of pure UiO-66- $\mathrm{NH}_{2}$ MOF nanoparticles [5]. The SEM images and FESEM images of UiO-66- $\mathrm{NH}_{2}$ MOF and PNVCL coated- UiO-66- $\mathrm{NH}_{2} /$ DOX MOF nanoparticles are illustrated in Fig.3. As shown, the uniform nanoparticles ranging from 100-200 nm were obtained for UiO$66-\mathrm{NH}_{2}$ MOF particles. The FESEM image of synthesized UiO-66- $\mathrm{NH}_{2} \mathrm{MOF}$ nanoparticles revealed the 
presence of irregular shapes (spherical and polyhedral) of UiO-66- $\mathrm{NH}_{2} \mathrm{MOF}$ nanoparticles with an average particle size of $175 \mathrm{~nm}$. The SEM image of PNVCL coated-UiO-66- $\mathrm{NH}_{2} / \mathrm{DOX}$ MOF indicated the increase in the particle sizes of particles. The particle sizes were obtained ranging from 100-300 nm with an average particle size of $235 \mathrm{~nm}$. The increase in particle sizes was further confirmed by the dynamic light scattering (DLS) measurements. As shown, the average hydrodynamic sizes of UiO-66- $\mathrm{NH}_{2} \mathrm{NMOFs}$ and DOX loaded-UiO-66- $\mathrm{NH}_{2}$ NMOFs were about $230 \mathrm{~nm}$ and $275 \mathrm{~nm}$, respectively.

Fig.2 XRD patterns of UiO-66- $\mathrm{NH}_{2}$ MOF and PNVCL coated- UiO-66/DOX MOF nanoparticles

Fig.3 (a) SEM and (b) FESEM images of UiO-66- $\mathrm{NH}_{2}$ MOF (c) SEM and (d) FESEM images PNVCL 1\% coated-UiO-66- $\mathrm{NH}_{2}$ /DOX MOF nanoparticles and (e) DLS of UiO-66- $\mathrm{NH}_{2}$ NMOFs and DOX loaded-UiO-66$\mathrm{NH}_{2} \mathrm{NMOFs}$

The FTIR spectra of UiO-66- $\mathrm{NH}_{2}$, UiO-66- $\mathrm{NH}_{2} / \mathrm{DOX}, \mathrm{PNVCL}$, and UiO-66- $\mathrm{NH}_{2} / \mathrm{DOX} / \mathrm{PNVCL}$ are illustrated in Fig.4. For UiO66- $\mathrm{NH}_{2}$ MOF nanoparticles, the observed peaks at $3450 \mathrm{~cm}^{-1}$ and $3360 \mathrm{~cm}^{-1}$ were attributed to the $\mathrm{OH}$ and $\mathrm{NH}$ stretching vibrations, respectively. The carboxylate groups of $\mathrm{BDC}^{-\mathrm{NH}_{2}}$ in the UiO-66$\mathrm{NH}_{2}$ structure were detected at $1575 \mathrm{~cm}^{-1}$ and $1390 \mathrm{~cm}^{-1}$. The observed peaks at $730 \mathrm{~cm}^{-1}, 665 \mathrm{~cm}^{-1}$, and $560 \mathrm{~cm}^{-1}$ were attributed to the $\operatorname{Zr}\left(\mu_{3}\right) O$ bands of MOF. The amide stretching vibration was detected at around $1730 \mathrm{~cm}^{-1}$ for pure UiO-66-NH $\mathrm{NH}_{2}$ MOF nanoparticles. The observed new peaks at $1710 \mathrm{~cm}^{-1}$ and $1610 \mathrm{~cm}^{-1}$ corresponding to the $\mathrm{C}=\mathrm{O}$ and $\mathrm{C}=\mathrm{C}$ groups of $\mathrm{DOX}$, demonstrated the loading of $\mathrm{DOX}$ molecules into the UiO66-NH2 NMOFs. Furthermore, the peaks of carboxylate groups of NMOFs were shifted from $1575 \mathrm{~cm}^{-1}$ and $1390 \mathrm{~cm}^{-1}$ to $1588 \mathrm{~cm}^{-1}$ and $1410 \mathrm{~cm}^{-1}$ after loading of DOX molecules into the NMOFs. For carboxylated PNVCL, the appeared bonds at $3425 \mathrm{~cm}^{-1}, 2920 \mathrm{~cm}^{-1}, 1620 \mathrm{~cm}^{-1}, 1480 \mathrm{~cm}^{-}$ $1,1420 \mathrm{~cm}^{-1}$, and $840 \mathrm{~cm}^{-1}$ were attributed to the carboxylic groups, $-\mathrm{CH}$ aliphatic groups, amide I absorption band, $\mathrm{C}-\mathrm{N}$ and $\mathrm{C}-\mathrm{H}$ stretching vibrations. For PNVCL coated NMOFs, the carbonyl peak intensity was increased at around $1720 \mathrm{~cm}^{-1}$.

The thermogravimetric analysis of UiO-66- $\mathrm{NH}_{2}$ NMOFs and PNVCL (1\% and $2 \%$ ) coated- UiO-66- $\mathrm{NH}_{2}$ NMOFs are illustrated in Fig.5. For UiO-66- $\mathrm{NH}_{2} \mathrm{NMOFs,} \mathrm{three} \mathrm{steps} \mathrm{of} \mathrm{weight} \mathrm{loss} \mathrm{occurred.} \mathrm{The} \mathrm{weight}$ loss at temperatures lower than $200^{\circ} \mathrm{C}$ could be attributed to the evaporation of solvents. The second weight loss ranging from $200-300^{\circ} \mathrm{C}$ was due to the dihydroxylation of $\mathrm{Zr}_{6} \mathrm{O}_{4}(\mathrm{OH})_{4}$ to $\mathrm{Zr}_{6} \mathrm{O}_{6}$ [43]. The main weight loss after $400^{\circ} \mathrm{C}$ could be attributed to the decomposition of organic groups. For PNVCL coated-UiO-66- $\mathrm{NH}_{2}$ NMOFs, the weight loss after $350^{\circ} \mathrm{C}$ was attributed to the pyrolysis of the PNVCL chains and decomposition of organic linkers of UiO-66- $\mathrm{NH}_{2}$.

The adsorption/desorption isotherms for UiO-66- $\mathrm{NH}_{2}$, UiO-66- $\mathrm{NH}_{2} / \mathrm{DOX}$ and PNVCL coated- UiO-66$\mathrm{NH}_{2}$ /DOX are illustrated in Fig.6. For UiO-66- $\mathrm{NH}_{2}$, the BET surface area and pore volume were found to be $1052 \mathrm{~m}^{2} \mathrm{~g}^{-1}$, and $0.58 \mathrm{~cm}^{2} \mathrm{~g}^{-1}$, respectively. After loading DOX into the NMOFs, the BET surface area and pore volume were decreased to $121 \mathrm{~m}^{2} \mathrm{~g}^{-1}$ and $0.12 \mathrm{~cm}^{2} \mathrm{~g}^{-1}$, respectively which demonstrated the high 
loading of DOX molecules into the pores of nanofibers. The blockage of NMOFs pores with DOX molecules resulted in a significant decrease in specific BET surface area after loading of DOX into the NMOFs. After the coating of PNVCL, the specific BET surface area and pore volume were decreased to 87 $\mathrm{m}^{2} \mathrm{~g}^{-1}$ and $0.08 \mathrm{~cm}^{2} \mathrm{~g}^{-1}$, respectively.

\subsection{Drug encapsulation efficiency, drug release, and kinetic studies}

The DOX encapsulation efficiency for NMOFs incubated at 10,50 and $100 \mu \mathrm{gmL}^{-1} \mathrm{DOX}$ is presented in Table 1. As shown in this table, the maximum drug encapsulation efficiency (DEE\%) was found to be $55.5 \%$ from $1 \%$ PNVCL coated-NMOFs containing $10 \mu \mathrm{g} / \mathrm{mL}$ DOX. By increasing DOX concentration, the DEE was gradually decreased. Furthermore, a coating of $2 \%$ PNVCL on the NMOFs surface resulted in a decrease of DEE in comparison to DEE of PNVCL 1\% coated-NMOFs in the same condition.

Table 1 Drug loading efficiency of synthesized UiO-66- $\mathrm{NH}_{2}$ /DOX/PNVCL NMOFs $(n=5)$

\begin{tabular}{|lll|}
\hline $\begin{array}{l}\text { PNVCL concentration } \\
(\%)\end{array}$ & $\begin{array}{l}\text { DOX concentration } \\
\left(\mu \mathrm{gm}^{-1}\right)\end{array}$ & $\begin{array}{l}\text { Drug loading efficiency } \\
(\%)\end{array}$ \\
\hline 1 & 10 & $55.5 \pm 2.3$ \\
\hline 1 & 50 & $52.6 \pm 2.1$ \\
\hline 1 & 100 & $49.9 \pm 1.6$ \\
\hline 2 & 10 & $46.6 \pm 1.5$ \\
\hline 2 & 50 & $42.2 \pm 1.4$ \\
\hline 2 & 100 & $38.9 \pm 1.3$ \\
\hline
\end{tabular}

The DOX release profiles of NMOFs containing $50 \mu \mathrm{g} \mathrm{mL}^{-1} \mathrm{DOX}$ at temperatures of $25^{\circ} \mathrm{C}, 37^{\circ} \mathrm{C}$ and $\mathrm{pH}$ values of 5.5 and 7.4 are illustrated in Fig. 7. As can be seen, the increase in pH from 5.5 to 7.4 and temperature from $25^{\circ} \mathrm{C}$ to $37^{\circ} \mathrm{C}$ resulted in a slower release of DOX from NMOFs coating with $1 \%$ and $2 \%$ PNVCL. Thus, the fastest release was achieved at pH of 5.5 and temperature of $25^{\circ} \mathrm{C}$. About $80 \% \mathrm{DOX}$ release occurred from 1\% PNVCL coated NMOFs after $48 \mathrm{~h}, 60 \mathrm{~h}, 72 \mathrm{~h}$, and $120 \mathrm{~h}$ at pH of 5.5, temperature of $25^{\circ} \mathrm{C}$, pH of 7.4 , Temperature of $25^{\circ} \mathrm{C}$, pH of 5.5 , Temperature of $37^{\circ} \mathrm{C}$ and $\mathrm{pH}$ of 7.4 , Temperature of $37^{\circ} \mathrm{C}$. Although, the DOX release mechanism was dependent on the temperature and $\mathrm{pH}$ variations, the effect of temperature on the release rate of DOX and its slower release was higher than that of $\mathrm{pH}$ effect on the declining release rate of DOX from NMOFs.

The comparison of correlation coefficients of pharmacokinetic models indicated that the KorsmeyerPeppas model $\left(R^{2}>0.99\right)$ was best described the DOX release data (Table 2). Furthermore, the " $n$ " values 
of the Korsmeyer-Peppas equation indicated the non-Fickian diffusion of the DOX release data of NMOFs under $\mathrm{pH}$ of 5.5 , Temperature of $25^{\circ} \mathrm{C}$, $\mathrm{pH}$ of 7.4 , Temperature of $25^{\circ} \mathrm{C}$ and $\mathrm{pH}$ of 5.5 , Temperature of 37 ${ }^{\circ} \mathrm{C}$ and Fickian diffusion of the DOX release data of NMOFs at pH of 7.4 and Temperature of $37^{\circ} \mathrm{C}$.

Table 2 Pharmacokinetic parameters of DOX release from NMOFs

\begin{tabular}{|c|c|c|c|c|c|c|c|c|c|}
\hline \multirow[t]{3}{*}{ Nanocarrier } & \multirow[t]{3}{*}{$\mathrm{pH}$} & \multirow{3}{*}{$\begin{array}{l}\text { Temperature } \\
\left({ }^{\circ} \mathrm{C}\right)\end{array}$} & \multicolumn{2}{|c|}{ Zero-order } & \multicolumn{2}{|c|}{ Higuchi } & \multicolumn{3}{|c|}{ Korsmeyer-Peppas } \\
\hline & & & $\mathrm{K}_{0}$ & $\mathrm{R}^{2}$ & & $\mathrm{R}^{2}$ & $\mathrm{n}$ & $\mathrm{K}_{\mathrm{KP}}$ & $\mathrm{R}^{2}$ \\
\hline & & & $\left(h r^{-1}\right)$ & & $\left(\mathrm{hr}^{-0.5}\right)$ & & & & \\
\hline \multirow{4}{*}{$\begin{array}{l}\text { UiO- } \\
66 / D O X / P N V C L \\
1 \%\end{array}$} & 7.4 & 25 & 0.222 & 0.932 & 2.952 & 0.944 & 0.664 & 3.65 & 0.995 \\
\hline & 7.4 & 37 & 0.182 & 0.944 & 2.545 & 0.955 & 0.410 & 2.98 & 0.994 \\
\hline & 5.5 & 25 & 0.232 & 0.925 & 3.192 & 0.954 & 0.712 & 4.23 & 0.993 \\
\hline & 5.5 & 37 & 0.202 & 0.936 & 2.777 & 0.950 & 0.548 & 3.33 & 0.994 \\
\hline \multirow{4}{*}{$\begin{array}{l}\text { UiO- } \\
66 / D O X / P N V C L \\
2 \%\end{array}$} & 7.4 & 25 & 0.218 & 0.935 & 2.811 & 0.954 & 0.601 & 3.44 & 0.994 \\
\hline & 7.4 & 37 & 0.175 & 0.939 & 2.324 & 0.960 & 0.384 & 2.62 & 0.993 \\
\hline & 5.5 & 25 & 0.212 & 0.932 & 2.944 & 0.950 & 0.652 & 3.86 & 0.996 \\
\hline & 5.5 & 37 & 0.196 & 0.943 & 2.553 & 0.958 & 0.508 & 3.11 & 0.995 \\
\hline
\end{tabular}

\subsection{Cytotoxicity of NMOFs}

The cytotoxicity of UiO-66- $\mathrm{NH}_{2}$, UiO-66- $\mathrm{NH}_{2} / \mathrm{PNVCL} 1 \%$, and UiO-66- $\mathrm{NH}_{2} / \mathrm{PNVCL} 2 \%$ against normal fibroblast cells are illustrated in Fig. 8a. The gradual decrease in the cell viability of pure UiO-66-NH2 by time could be attributed to the $\mathrm{Zr}-\mathrm{O}$ clusters release into the medium which increased the cytotoxicity of cells treated with fibroblast cells treated with UiO-66- $\mathrm{NH}_{2}$ NMOFs. Whereas, there was no significant cytotoxicity toward fibroblast normal cells treated with PNVCL coated-NMOFs.

The cytotoxicity of pure UiO-66- $\mathrm{NH}_{2}$ NMOFs, pristine DOX $\left(100 \mu \mathrm{g} \mathrm{mL}^{-1}\right)$, UiO-66- $\mathrm{NH}_{2} / \mathrm{DOX} 50 \mu \mathrm{g} \mathrm{mL}^{-1}$, UiO-66- $\mathrm{NH}_{2} /$ DOX $100 \mu \mathrm{g} \mathrm{mL}{ }^{-1}$, PNVCL $1 \%$ and PNVCL $2 \%$ coated- UiO-66- $\mathrm{NH}_{2} /$ DOX NMOF samples against A549 lung cancer cells is illustrated in Fig.8b. As shown, there was a little cytotoxicity of UiO-66$\mathrm{NH}_{2}$ NMOFs against $A 549$ cells after $72 \mathrm{~h}$. The cytotoxicity of pure DOX was found to be $66 \%$ against A549 lung cancer cells. By loading 50 and $100 \mu \mathrm{g} \mathrm{mL}^{-1}$ DOX into the UiO-66- $\mathrm{NH}_{2} \mathrm{NMOFs}$, the cytotoxicity of NMOFs was increased to $56 \%$ and $45 \%$ against A549 lung cancer cells after $72 \mathrm{~h}$ incubation time for the UiO-66- $\mathrm{NH}_{2} / \mathrm{DOX} 50 \mu \mathrm{g} \mathrm{mL}^{-1}$ and UiO-66- $\mathrm{NH}_{2} / \mathrm{DOX} 100 \mu \mathrm{gL} \mathrm{L}^{-1}$, respectively. The maximum 
cytotoxicity of A549 cancer cells was about $76 \%$ in the presence of PNVCL $1 \%$ coated- UiO-66- $\mathrm{NH}_{2} / \mathrm{DOX}$ $100 \mu \mathrm{g} \mathrm{mL}^{-1}$ NMOFs. Coating of NMOFs with $2 \%$ PNVCL resulted in decreasing the cytotoxicity of NMOFs against A549 cancer cells.

The DAPI staining images of untreated A549 cells and A549 cells treated UiO-66- $\mathrm{NH}_{2} / \mathrm{DOX} 100 \mu \mathrm{g} \mathrm{mL}^{-1}$ NMOFs and NMOFs coated with $1 \%$ and $2 \%$ PNVCL after $72 \mathrm{~h}$ incubation time are illustrated in Fig. 9. As shown, the nuclear fragmentation in their chromatin of cells was detected in the presence of $100 \mathrm{\mu g} \mathrm{mL}^{-1}$ DOX loaded-NMOFs and NMOFs/DOX coated with $1 \%$ and $2 \%$ PNVCL.

\section{Discussion}

The comparison of XRD patterns of UiO-66- $\mathrm{NH}_{2}$ MOF and PNVCL coated UiO-66- $\mathrm{NH}_{2} / \mathrm{DOX}$ MOF indicated that the incorporation of DOX into the MOF and coating with PNVCL resulted in the weakening of diffraction peaks of UiO-66- $\mathrm{NH}_{2}$ MOF due to decreasing the X-ray contrast of MOF pore cages. Furthermore, no diffraction peaks were detected in the XRD pattern of PNVCL coated-UiO-66- $\mathrm{NH}_{2} / \mathrm{DOX}$ MOF nanoparticles which indicated the amorphous status of PNVCL and DOX in the UiO-66/DOX/PNVCL matrix. The increase in the particle size of UiO-66/DOX/PNVCL was due to the incorporation of DOX molecules into the MOF nanoparticles and its coating with PNVCL polymer. The FESEM image of PNVCL $1 \%$ coated- UiO-66- $\mathrm{NH}_{2} / \mathrm{DOX}$ particles demonstrated an appropriate coating of the UiO-66- $\mathrm{NH}_{2}$ surface with PNVCL. The comparison of SEM and DLS results indicated that the average particle sizes of synthesized NMOFs reported by SEM were lower than that of DLS. The hydrodynamic radius of MOFs was found to be higher than that of particle sizes of dried nanoparticles. Similar trends were reported by other researchers $[40,41]$. The comparison of FTIR spectra of pure PNVCL and PNVCL 1\% coated- UiO-66$\mathrm{NH}_{2}$ /DOX indicated that the carboxyl peak intensity in the FTIR spectrum of UiO-66- $\mathrm{NH}_{2}$ /DOX/PNVCL was decreased in comparison to the carboxyl peak intensity of pure PNVCL which could be attributed to the interaction of carboxylic groups of PNVCL with amine groups of UiO-66- $\mathrm{NH}_{2}$ [42]. Furthermore, the appeared new band at $1522 \mathrm{~cm}-1$ corresponding to the amide II groups revealed the interaction of PNVCL polymer and UiO-66- $\mathrm{NH}_{2}$ NMOFs. The comparison of TGA curves of UiO-66- $\mathrm{NH}_{2} \mathrm{NMOFs}$, and PNVCL (1\% and $2 \%$ ) coated- UiO-66- $\mathrm{NH}_{2}$ NMOFs indicated that the polymer percentages coated on the UiO-66- $\mathrm{NH}_{2}$ NMOFs surface were found to be $17.5 \%$, and $27.3 \%$ for NMOFs incubated in $1 \%$ and $2 \%$ PNVCL solution, respectively. The BET analysis results indicated that the blockage of NMOFs pores with DOX molecules resulted in a significant decrease in specific BET surface area after loading of DOX into the NMOFs. After the coating of PNVCL, the specific BET surface area and pore volume were decreased to $87 \mathrm{~m}^{2} \mathrm{~g}^{-1}$ and $0.08 \mathrm{~cm}^{2} \mathrm{~g}^{-1}$, respectively in comparison to high BET surface area $\left(1052 \mathrm{~m}^{2} \mathrm{~g}^{-1}\right)$ and high pore volume of bare UiO-66- $\mathrm{NH}_{2}$ NMOFs $\left(0.58 \mathrm{~cm}^{2} \mathrm{~g}^{-1}\right)$.

The release profiles results indicated the faster release of DOX from PNVCL 1\% coated-NMOFs in comparison to PNVCL $2 \%$ coated-NMOFs. This behavior could be attributed to the easier diffusion of DOX 
molecules from NMOFs containing PNVCL 1\% due to the lower thickness of PNVCL formed on the NMOFs surface. The loss of some interactions between $\mathrm{Zr}-\mathrm{O}$ clusters/DOX and UiO-66- $\mathrm{NH}_{2} / \mathrm{PNVCL}$ resulted in the faster release of DOX from NMOFs at pH of 5.5 in comparison to DOX release at pH of 7.4. At $25^{\circ} \mathrm{C}$, the swelling of PNVCL ON THE NMOFs surface resulted in a faster release of DOX from NMOFs. Whereas, the collapse of the PNVCL matrix at temperature higher than LCST (lower critical solution temperature) of PNVCL $\left(32{ }^{\circ} \mathrm{C}\right)$ resulted in slower diffusion of drug molecules from PNVCL and slower release of DOX at physiological temperature. A similar trend was reported by Rao et al. for 5-FU release from PNVCL nano gel [31].

The biocompatibility of UiO-66- $\mathrm{NH}_{2}$ /PNVCL $1 \%$ and UiO-66- $\mathrm{NH}_{2}$ /PNVCL $2 \%$ was higher than pure UiO-66$\mathrm{NH}_{2}$ NMOFs due to its coating with biocompatible PNVCL. The gradual cytotoxicity of UiO-66- $\mathrm{NH}_{2} \mathrm{NMOFs}$ against A549 cells after $72 \mathrm{~h}$ was due to the release of clusters of UiO-66- $\mathrm{NH}_{2} \mathrm{NMOFs}$ into the medium. The controlled release of DOX from DOX loaded- UiO-66- $\mathrm{NH}_{2} \mathrm{NMOFs}$ is responsible for higher antitumor efficacy of DOX loaded-UiO-66- $\mathrm{NH}_{2} \mathrm{NMOFs}$ in comparison to pristine DOX. The coating of PNVCL on the UiO-66- $\mathrm{NH}_{2} / \mathrm{DOX}$ surface resulted in the continuous release of DOX and enhancement in cytotoxicity after $72 \mathrm{~h}$. Whereas, the lower cytotoxicity of PNVCL $1 \%$ and $2 \%$ coated- UiO-66- $\mathrm{NH}_{2} / \mathrm{DOX}$ after $24 \mathrm{~h}$ incubation time in comparison to the cytotoxicity of UiO-66- $\mathrm{NH}_{2} / \mathrm{DOX}$ could be attributed to the lower content of DOX in the medium due to the sustained release of DOX from PNVCL coated UiO-66- $\mathrm{NH}_{2} / \mathrm{DOX}$. The DAPI staining results indicated the higher fragmentized nuclei of cells treated with UiO-66- $\mathrm{NH}_{2} / \mathrm{DOX} 100 \mu \mathrm{g} \mathrm{mL}^{-}$ $1 /$ PNVCL $1 \%$. Therefore, this formulation could be considered as an optimum formulation for the A549 cancer cells death.

\section{Conclusion}

The PNVCL coated- UiO-66- $\mathrm{NH}_{2} /$ DOX NMOFs were successfully synthesized and its application was investigated for controlled release of DOX against A549 lung cancer cells. The XRD and FESEM image of UiO-66- $\mathrm{NH}_{2}$ NMOFs demonstrated the formation of crystalline nanoparticles with an average particle size of $175 \mathrm{~nm}$. The FTIR spectra of PNVCL coated NMOFs revealed the interaction of carboxylic groups of PNVCL with amine groups of UiO-66-NH2. Based on TGA results, the PNVCL polymer percentages coated on the UiO-66- $\mathrm{NH}_{2}$ NMOFs surface were found to be $17.5 \%$, and $27.3 \%$ for NMOFs incubated in $1 \%$ and $2 \%$ PNVCL solutions. The BET surface area and pore volume of UiO-66- $\mathrm{NH}_{2} \mathrm{NMOFs}$ were found to be $1052 \mathrm{~m}^{2} \mathrm{~g}^{-1}$, and $0.58 \mathrm{~cm}^{2} \mathrm{~g}^{-1}$, respectively. The maximum drug encapsulation efficiency (DEE \%) was found to be $55.5 \%$ from NMOFs coated with $1 \%$ PNVCL and $10 \mu \mathrm{gL}^{-1} \mathrm{DOX}$. The DOX release percentage from $1 \%$ PNVCL coated NMOFs was achieved to $80 \%$ within $48 \mathrm{~h}, 60 \mathrm{~h}, 72 \mathrm{~h}$, and $120 \mathrm{~h}$ under $\mathrm{pH}$ of 5.5, temperature of $25^{\circ} \mathrm{C}, \mathrm{pH}$ of 7.4 , the temperature of $25^{\circ} \mathrm{C}, \mathrm{pH}$ of 5.5 , the temperature of $37^{\circ} \mathrm{C}$ and $\mathrm{pH}$ of 7.4 , the temperature of $37^{\circ} \mathrm{C}$. The Korsmeyer-Peppas model was best described the DOX release data of synthesized NMOFs. There was no significant cytotoxicity toward fibroblast normal cells treated with PNVCL coated-NMOFs. Whereas, the maximum cytotoxicity of A549 cancer cells was about $76 \%$ in the presence of PNVCL $1 \%$ coated- UiO-66-NH 2 /DOX $100 \mu \mathrm{g} \mathrm{mL}^{-1}$ NMOFs. Therefore, the loading of DOX into 
the NMOFs, and its surface coating with PNVCL improved the efficiency of chemotherapy for targeted delivery of DOX against lung cancer compared to unloaded DOX.

\section{References}

1. A.R. Abbasi, S. Hatami, J. Inorg. Organomet. Polym Mater. 27, 1941 (2017)

2. S. Beg, M. Rahman, A. Jain, S. Saini, P. Midoux, C. Pichon, F.J. Ahmad, S.Akhter. Drug Discov. Today 22, 625 (2017)

3. D. Wei, Y. Xin, Y. Rong, Y. Li, C. Zhang, Q. Chen, S. Qin, W. Wang, Y. Hao.. J Inorg Organomet Polym Mater 30, 1121 (2020)

4. A. Bhattacharjee, M.K. Purkait, S. Gumma, J. Inorg. Organomet. Polym Mater. 30, 2366 (2020)

5. A. Bazzazzadeh, B.F. Dizaji, N. Kianinejad, A. Nouri, M. Irani. Int. J. Pharm. 587, 119674 (2020)

6. J.R. Bi, Y. Zheng, L.Q. Fang, Y.C. Guan, A.Q. Ma, J. Wu. J Inorg Organomet Polym Mater 30, 3388 (2020)

7. A. Farboudi, K. Mahboobnia, F. Chogan, M.Karimi,A. Askari, S. Banihashem, S. Davaran, M.Irani. Int. J. Biol. Macromol. 150, 178 (2020)

8. P. Kush, T. Bajaj, M. Kaur, J. Madan, U.K. Jain, P. Kumar, A. Deep, K.H. Kim, J. Inorg. Organomet. Polym Mater. 30, 2827 (2020)

9. F.Su,Q. Jia, Z. Li, M. Wang, L. He, D. Peng, Y. Song, Z. Zhang, S.Fang. Microporous Mesoporous Mater. 275, 152 (2019)

10. A.R. Chowdhuri, T. Singh, S.K. Ghosh, S.K. Sahu, ACS Appl 8, 16573 (2016)

11. B.M. Jarai., Z. Stillman, L. Attia, G.E. Decker, E.D. Bloch, C.A. Fromen, ACS Appl 12, 35 (2020)

12. M.X. Wu, Y.W. Yang, Adv. Mater 29, 1606134 (2017)

13. X. Ke, N. Qin, T. Zhang, F. Ke, X. Yan, J. Inorg. Organomet. Polym Mater. 30, 935 (2020)

14. A. Ebrahimpour, N.R. Alam, P. Abdolmaleki, B. Hajipour-Verdom, F. Tirgar, T. Ebrahimi, M. Khoobi, J. Inorg. Organomet. Polym Mater. 31, 1208 (2021)

15. J. X.Zhu.Gu, Y.Wang, B.Li, Y.Li, W..Zhao, J.Shi. ChemComm 50, 8779 (2014)

16. I.A. Lázaro, S. Haddad, S. Sacca, C.Orellana -Tavra, D.F. Jimenez, R.S. Forgan. Chem 2, 561 (2017)

17. M. Nasrabadi, M.A. Ghasemzadeh, M.R. Zand Monfared. New J Chem 43, 16033 (2019)

18. A.R. Chowdhuri, D. Laha, S. Chandra, P. Karmakar, S.K..Sahu. Chem. Eng. J. 319, 200 (2017)

19. H.X. Zhao, Q. Zou, S.K. Sun, C.Yu,X. Zhang, R.J. Li, Y.Y.Fu. Chem. Sci. 7, 5294 (2016)

20. J. L.Tang.Shi, X.Wang, S..H. Zhang.H. Wu.Sun, Z.Jiang. Nanotechnology 28, 275601 (2017)

21. C.S. Y.Liu, Gong, Y.Dai, Z.Yang, G..Y. Yu.Liu, M.Zhang,. Biomaterials 218, 119365 (2019)

22. A. D.Giliopoulos.D. Zamboulis.D. Giannakoudakis.Bikiaris, K.Triantafyllidis. Molecules 25, 185 (2020)

23. W.Cai,J. Wang, C. Chu, W. Chen, C. Wu, G.Liu. Adv. Sci. 6, 1801526 (2019)

24. C. Liu, X. Xu, J. Zhou, J.Yan,D. Wang, H.Zhang. BMC Mater 2, 1 (2002) 
25. S. Javanbakht, M. Pooresmaeil, H.Hashemi, HNamazi. Int. J. Biol. Macromol. 119, 588 (2018)

26. T.A. Vahed, M.R. Naimi-Jamal, L.Panahi. New J Chem 42, 11137 (2018)

27. A. Singh, K. Vaishagya, R.K. Verma, R.Shukla. AAPS PharmSciTech 20, 213 (2019)

28. Y.C. Chen, C.L. Lo, G.H. Hsiue, J Biomed Mater Res A. 102, 2024 (2014)

29. T.Kavitha, I.K.Kang, S.Y.Park, Colloids Surf. B 115, 37 (2014)

30. M.N. Mohammed, K. B.Yusoh, J.H.B.H. Shariffuddin, Mater. Res. Express 8, 21 (2018)

31. K.M. Rao, B. Mallikarjuna, K.S.V.K. Rao, S. Siraj, K. C.Rao, M. C. S. Subha. Colloids Surf. B 102, 891 (2013)

32. M.Beija, J.D..Marty, M.Destarac. Chem.Comm 47, 2826 (2011)

33. D.S. Chauhan, S. Indulekha, R. Gottipalli, B.P.K. Reddy, T.R. Chikate, R. .Gupta, D.N. Jahagirdar, R.Prasad, A. De, R.Srivastava. RSC Adv. 7, 44026 (2017)

34. M.N. Mohammed, K.B. .Yusoh, J.H.B.H.Shariffuddin. Mater. Res. Express 8, 21 (2018)

35. S. Banihashem, Ma.N. Nezhati, H.A.Panahia. Carbohydr 227, 115333 (2020)

36. T.Higuchi. J. Pharm. Sci. 52, 1145 (1963)

37. R.W. Korsmeyer, R. Gurny, E.Doelker,P.Buri,,N.A. Peppas, Int. J. Pharm. 15, 25 (1983)

38. R. Salehi, M.Irani,M. Eskandani, K. Nowruzi, S. Davaran, I.Haririan. Int. J. Polym. Mater. 63, 609 (2014)

39. B.F. Dizaji, M.H. Azerbaijan, N. Sheisi, P. Goleij, T. Mirmajidi, F. Chogan, M. Irani, F.Sharafian. Int. J. Biol. Macromol. 164, 1461 (2002)

40. J. You, W. Li, C. Yu, C. Zhao, L. Jin, Y. Zhou, O. Wang, O. J. Nanoparticle Res. 15, 1 (2013)

41. S. Guo, Y. Qiao, W. Wang, H. He, L. Deng, J. Xing, A. Dong, J. Mater. Chem. 20, 6935 (2010)

42. Z. Liang, Z. Yang, H. Yuan, C. Wang, J. Qi, K. Liu, R. Cao, H.Zheng. Dalton Trans. 47, 10223 (2018)

43. E.Y. Kim, H.S. Kim, D. Kim, J. Kim, P. S. Lee. Crystals 9, 15 (2019)

\section{Figures}


(a)

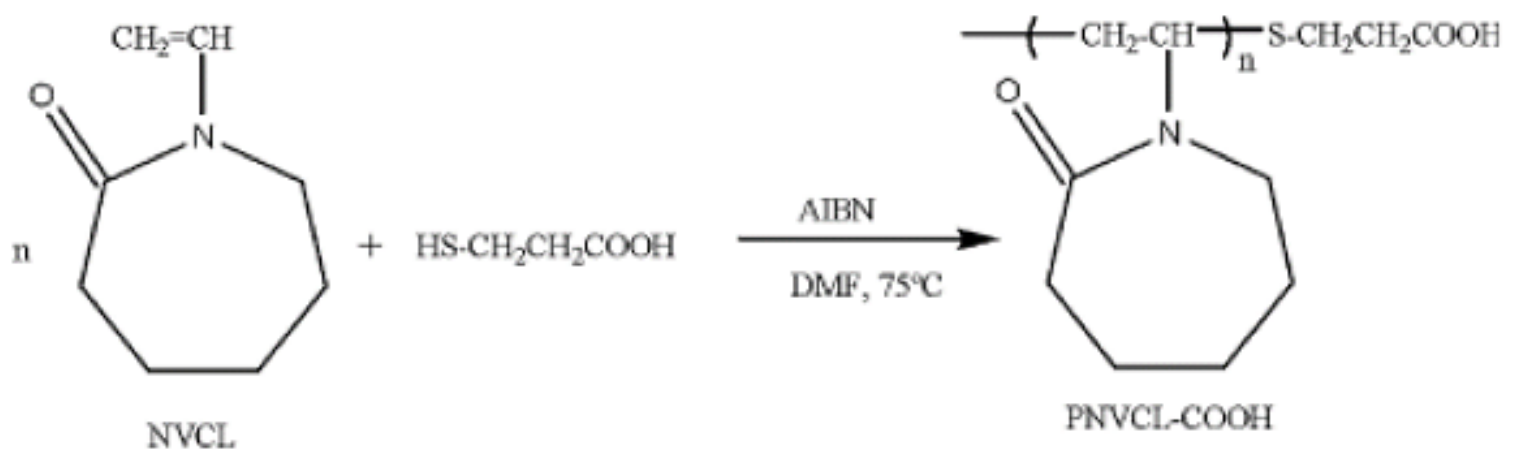

(b)

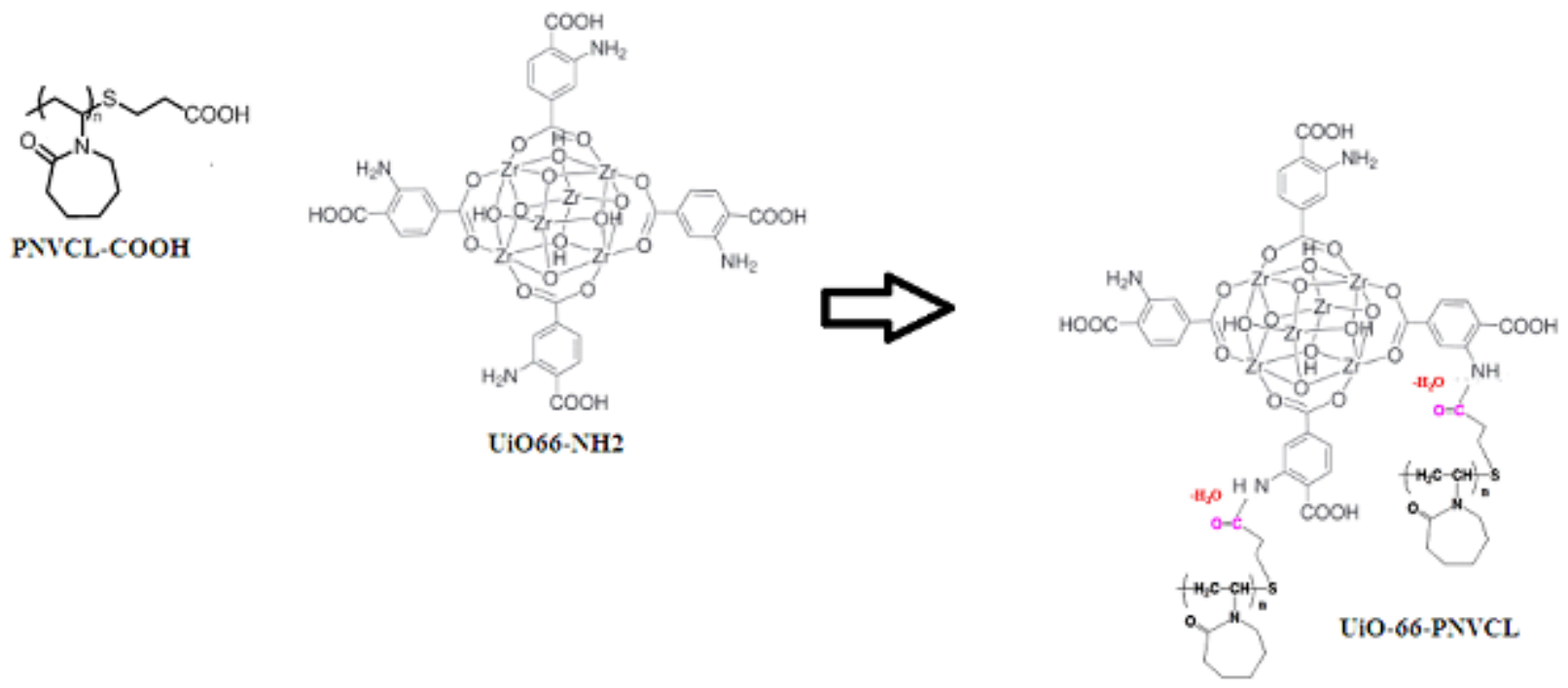

Figure 1

(a) Mechanism of the synthesis of (a) PNVCL and (b) UiO-66/NH2/PNVCL 


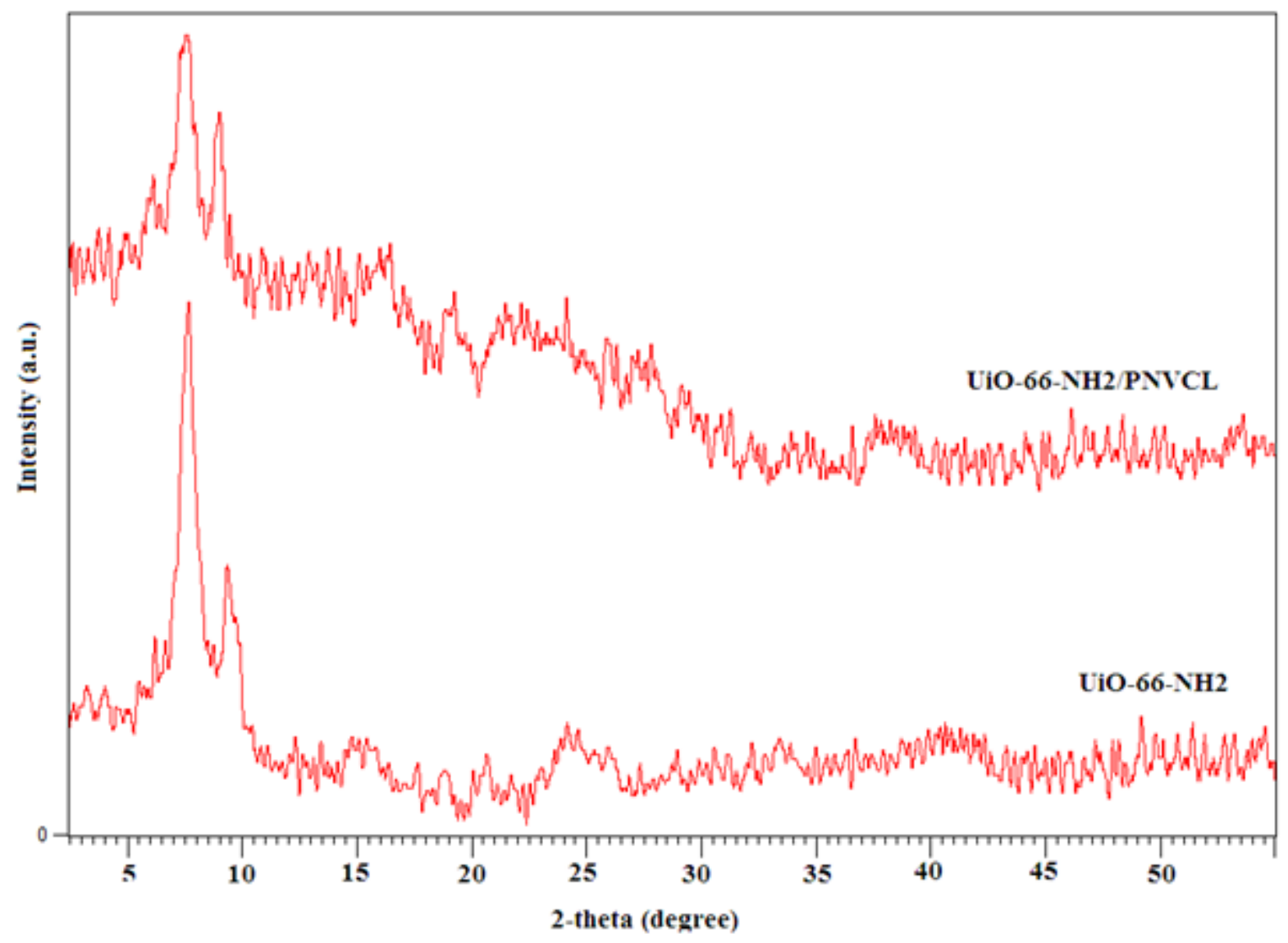

Figure 2

XRD patterns of UiO-66-NH2 MOF and PNVCL coated- UiO-66/DOX MOF nanoparticles 
(a)

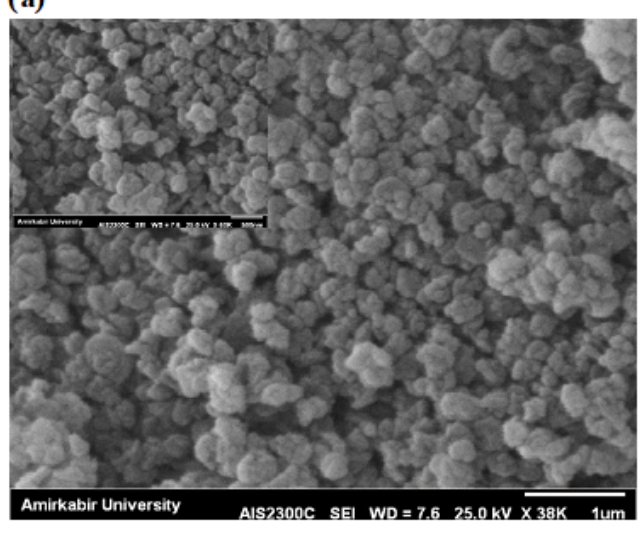

(c)

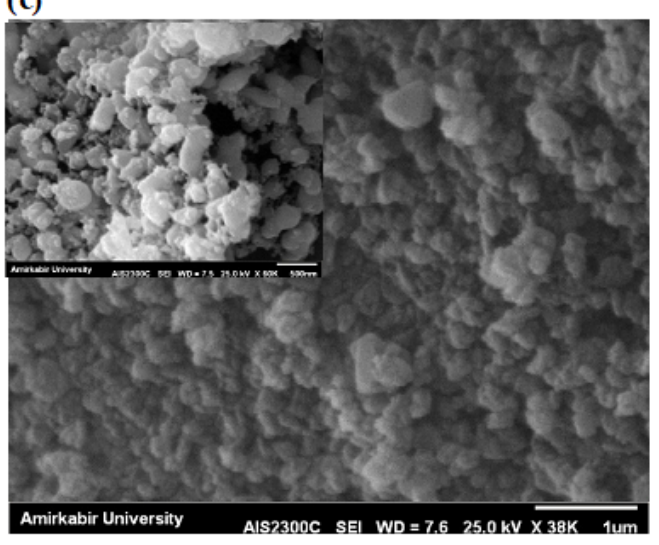

(b)

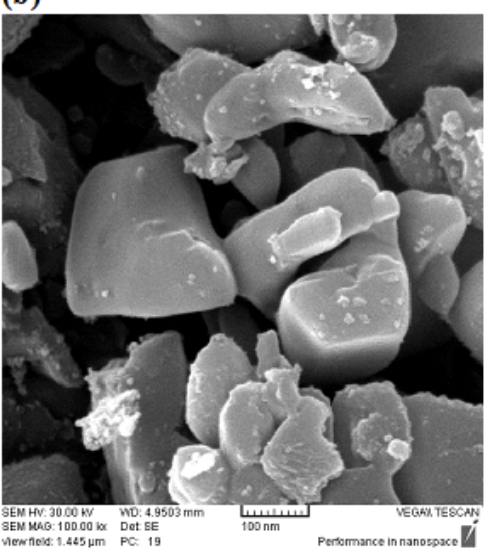

(d)

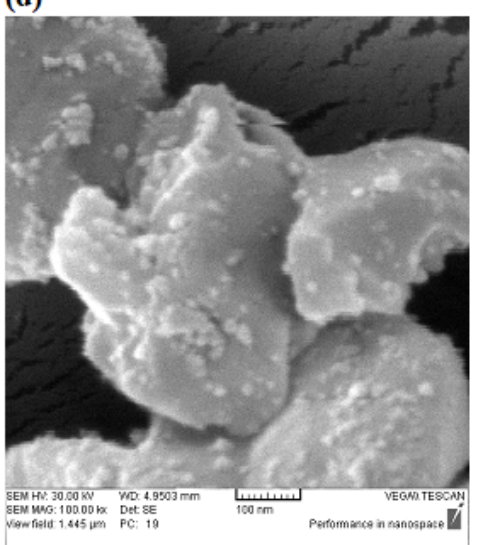

(e)

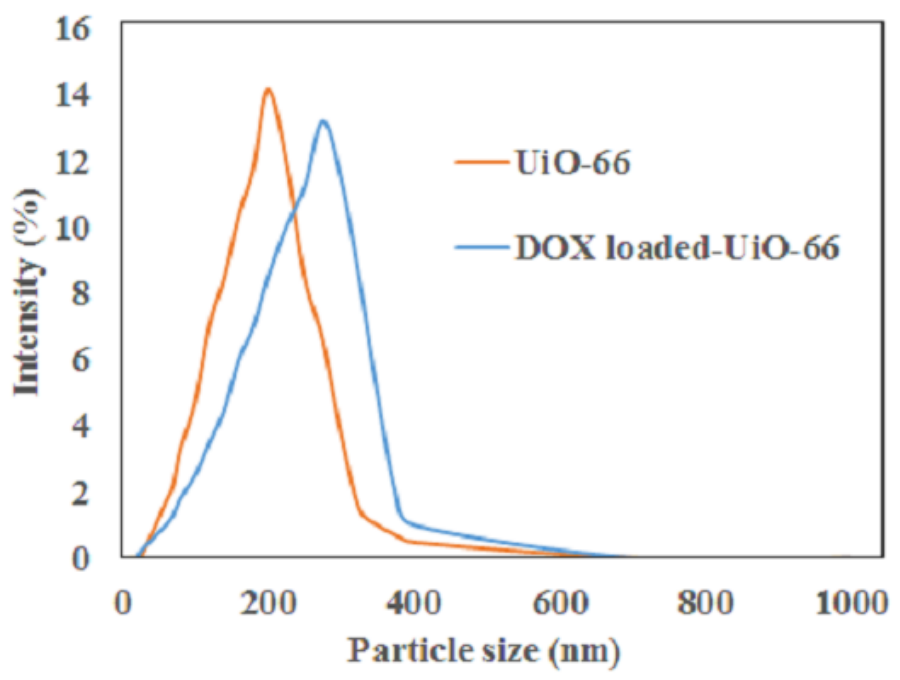

Figure 3

(a) SEM and (b) FESEM images of UiO-66-NH2 MOF (c) SEM and (d) FESEM images PNVCL 1\% coatedUiO-66-NH2/DOX MOF nanoparticles and (e) DLS of UiO-66-NH2 NMOFs and DOX loaded-UiO-66-NH2 NMOFs 


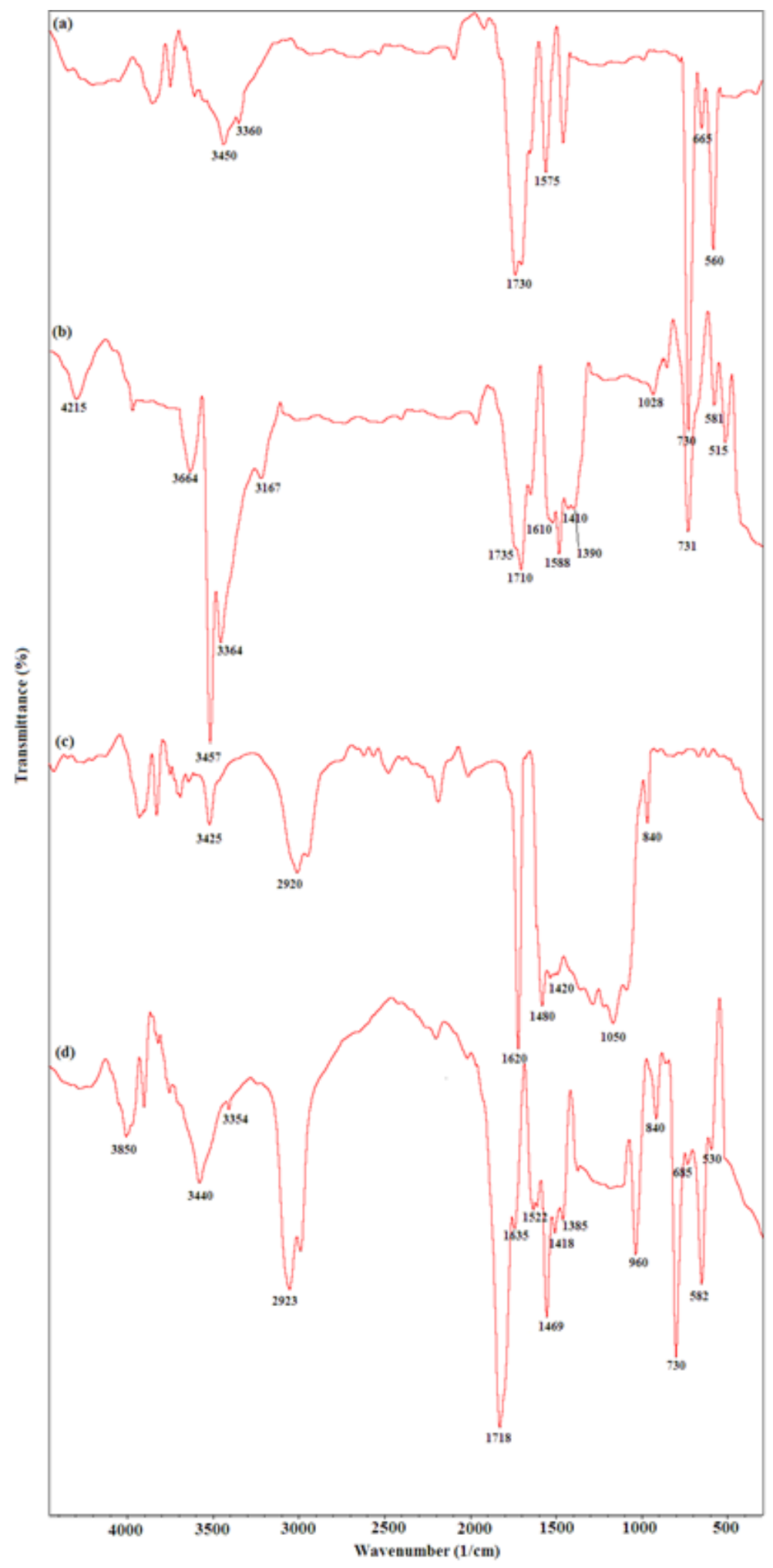

Figure 4

FTIR spectra of (a) UiO-66-NH2, (b) UiO-66-NH2/DOX, (c) PNVCL and (d) UiO-66/DOX/PNVCL 


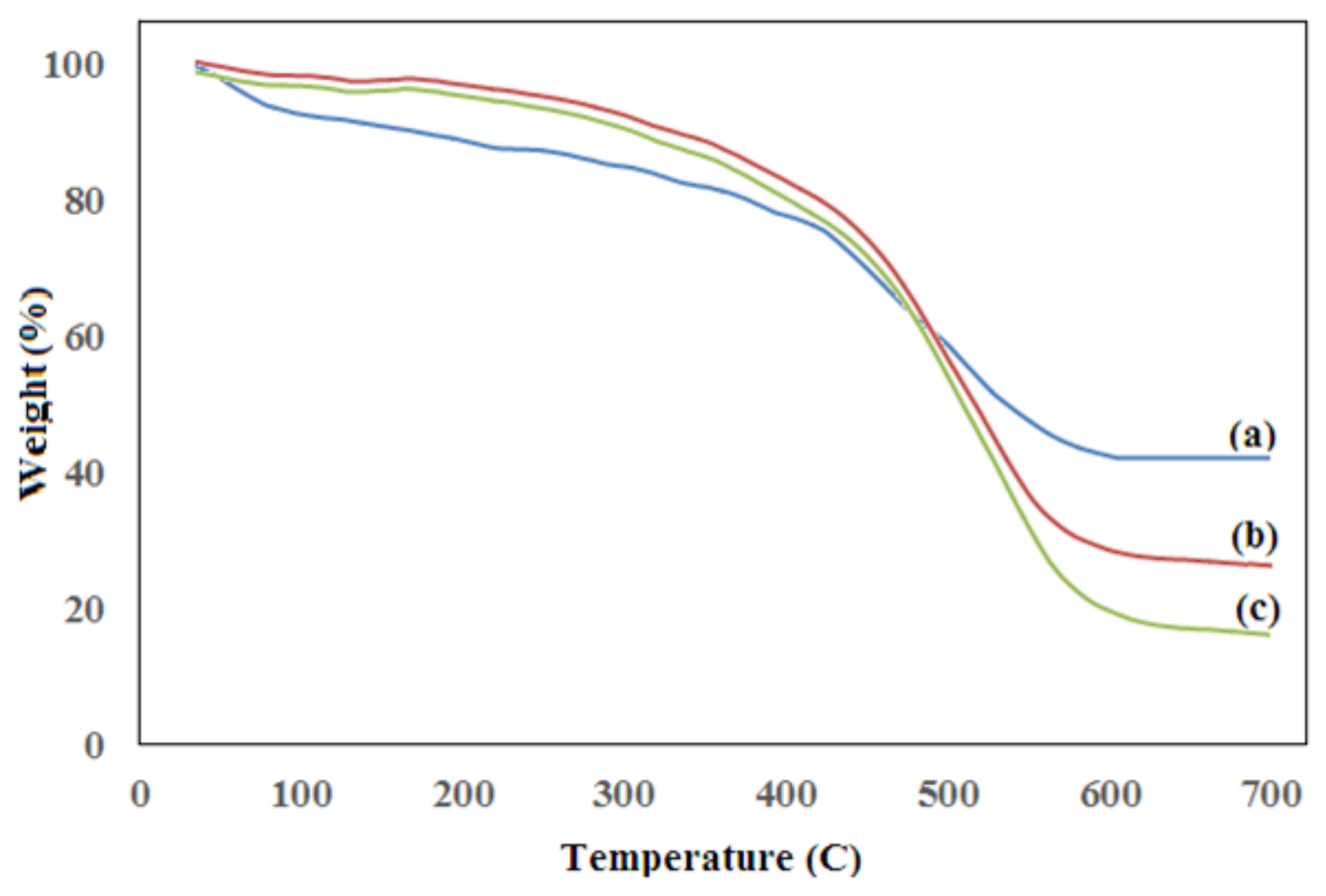

Figure 5

TGA curves of (a) UiO-66-NH2 NMOFs, (b) PNVCL 1\%, (c) PNVCL 2\% coated-UiO-66-NH2 NMOFs 


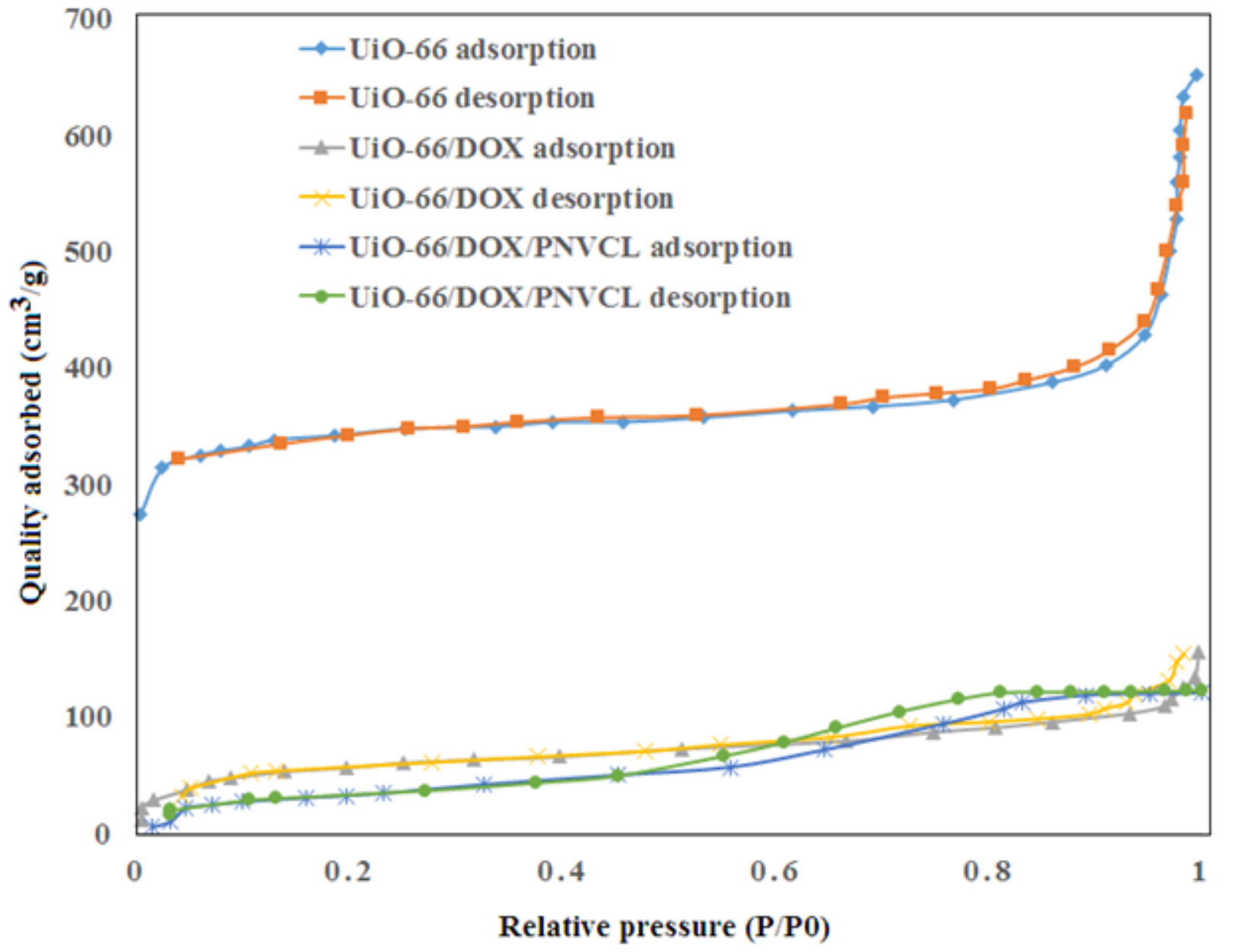

\section{Figure 6}

Nitrogen adsorption/desorption isotherms of UiO-66-NH2, UiO-66-NH2/DOX and UiO-66-NH2/DOX/PNVCL samples 


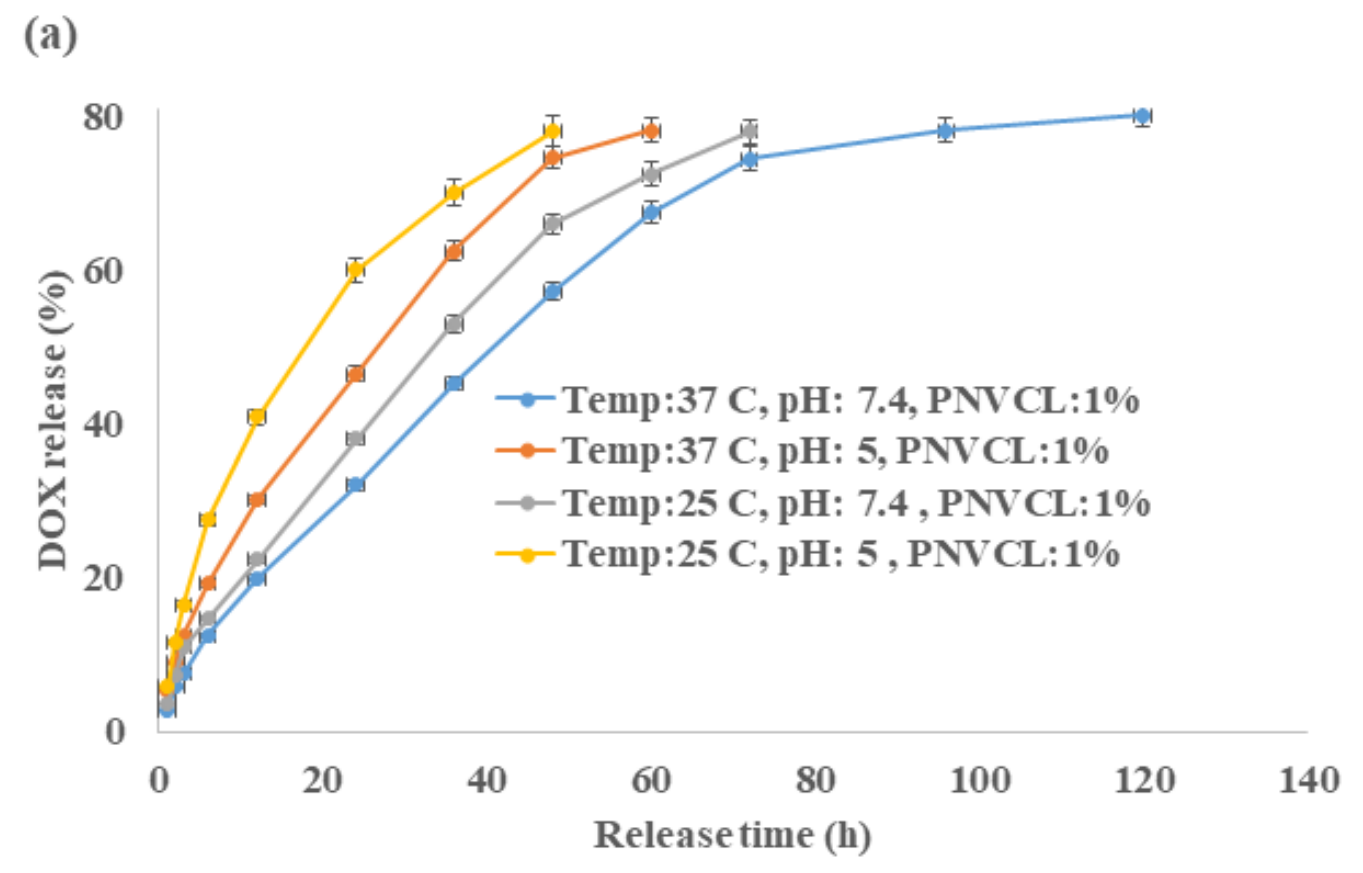

(b)

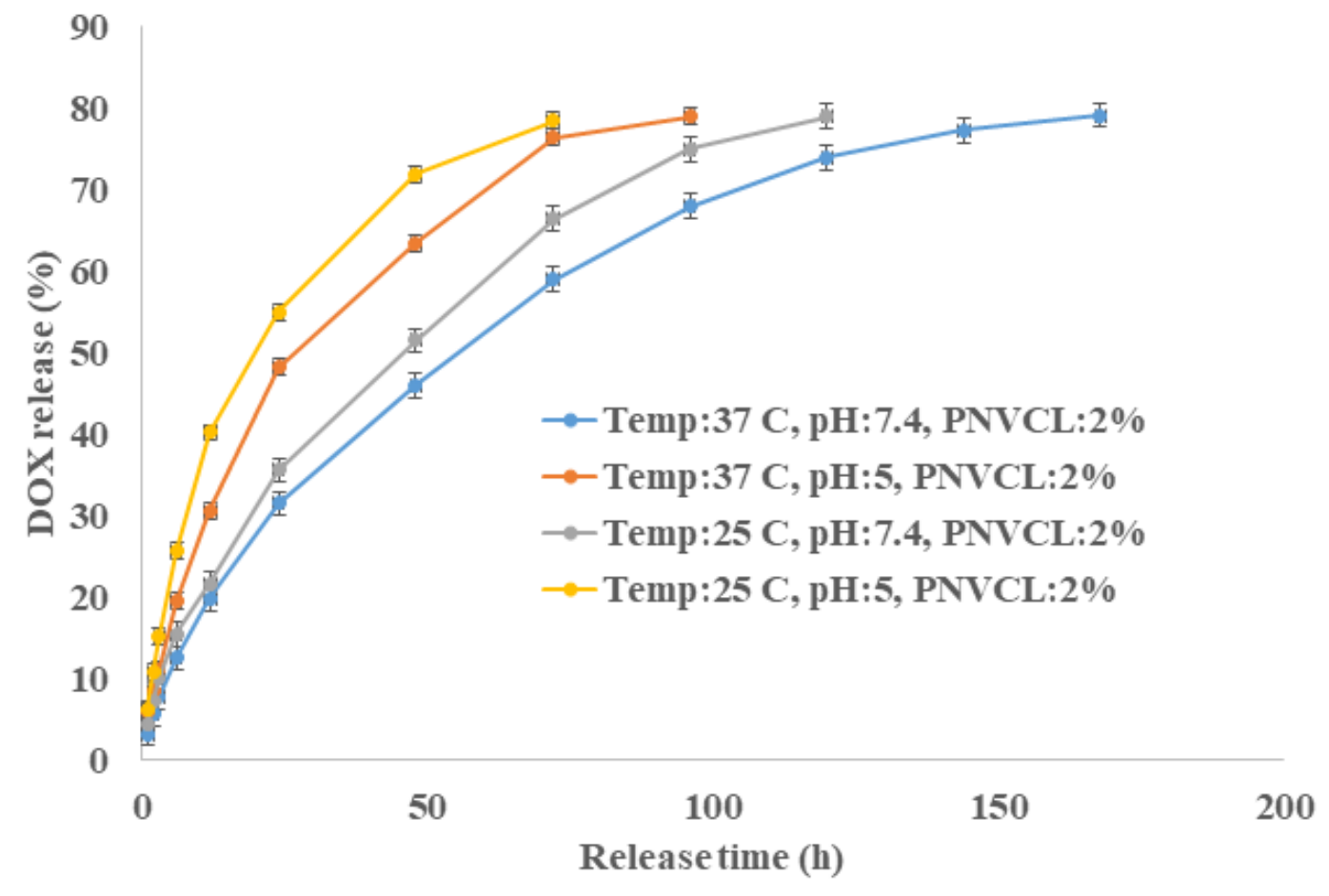

Figure 7

DOX release profiles of (a) PNVCL 1\% coated- NMOFs and (b) PNVCL 2\% coated- NMOFs containing 50 $\mu \mathrm{g} \mathrm{mL}-1 \mathrm{DOX}$ under temperatures of $25^{\circ} \mathrm{C}, 37^{\circ} \mathrm{C}$ and $\mathrm{pH}$ values of 5.5 and 7.4 


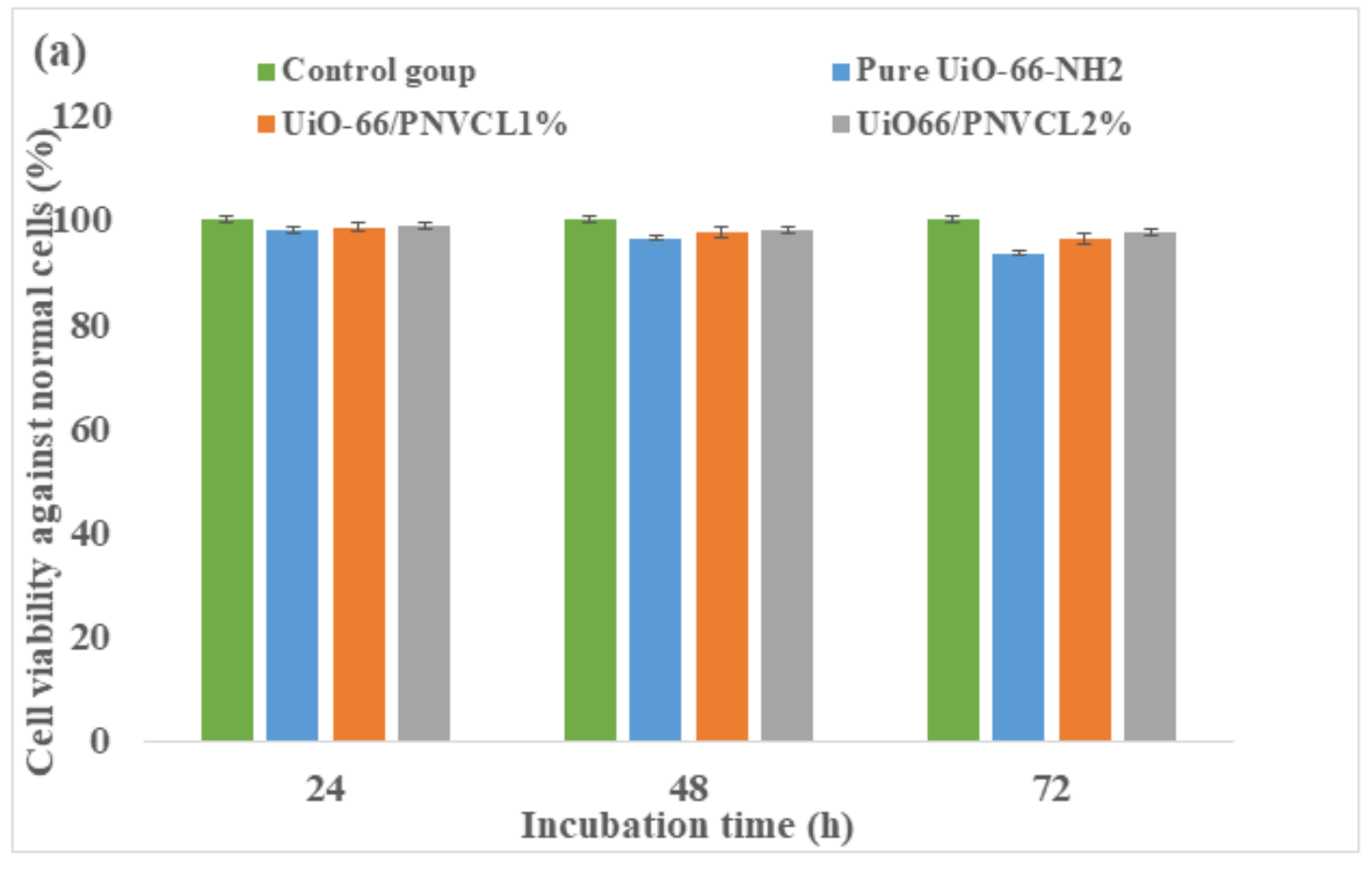

(b)

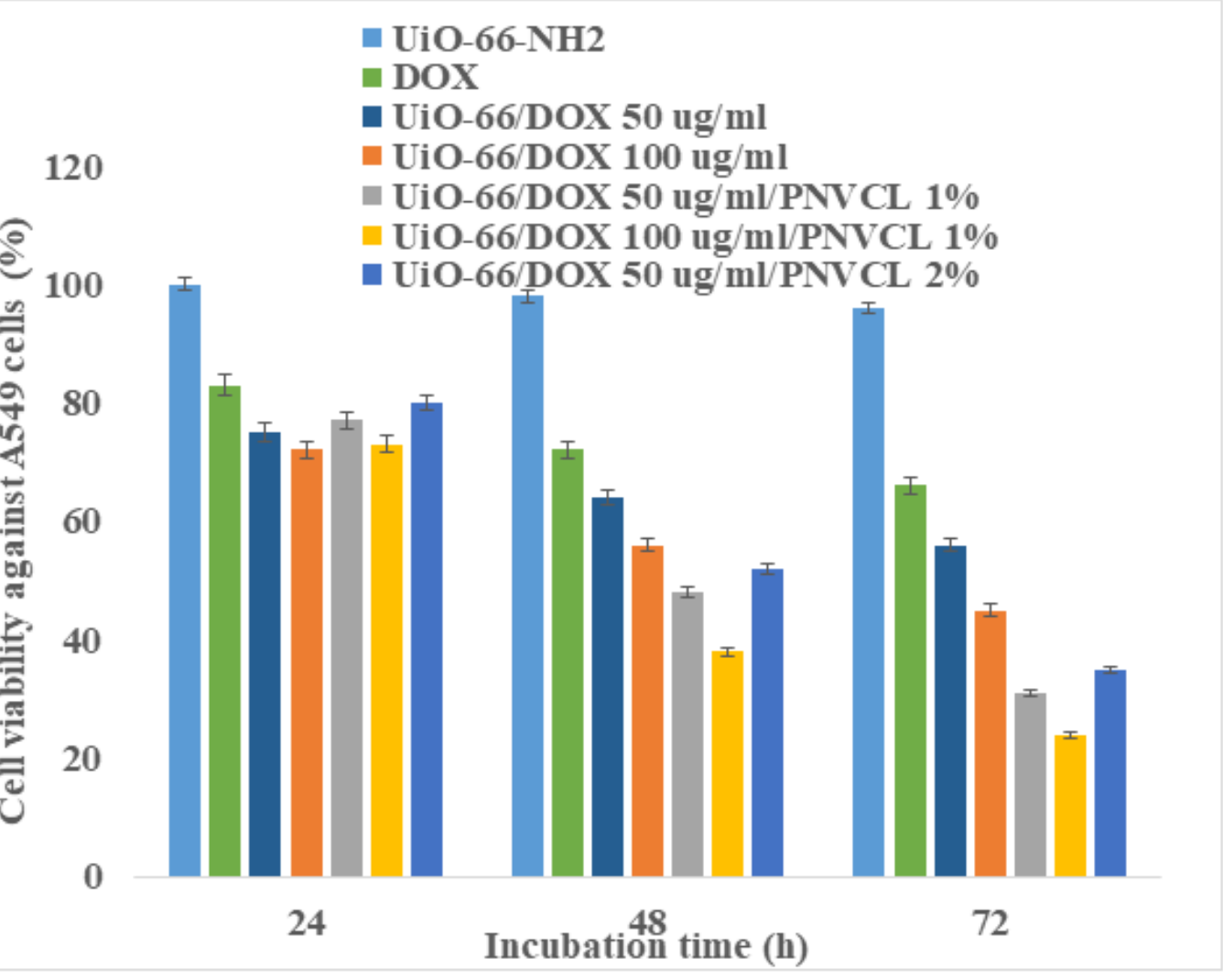

\section{Figure 8}

Cell viability of NMOFs samples against (a) normal fibroblast cells and (b) A549 lung cancer cells 
(a)

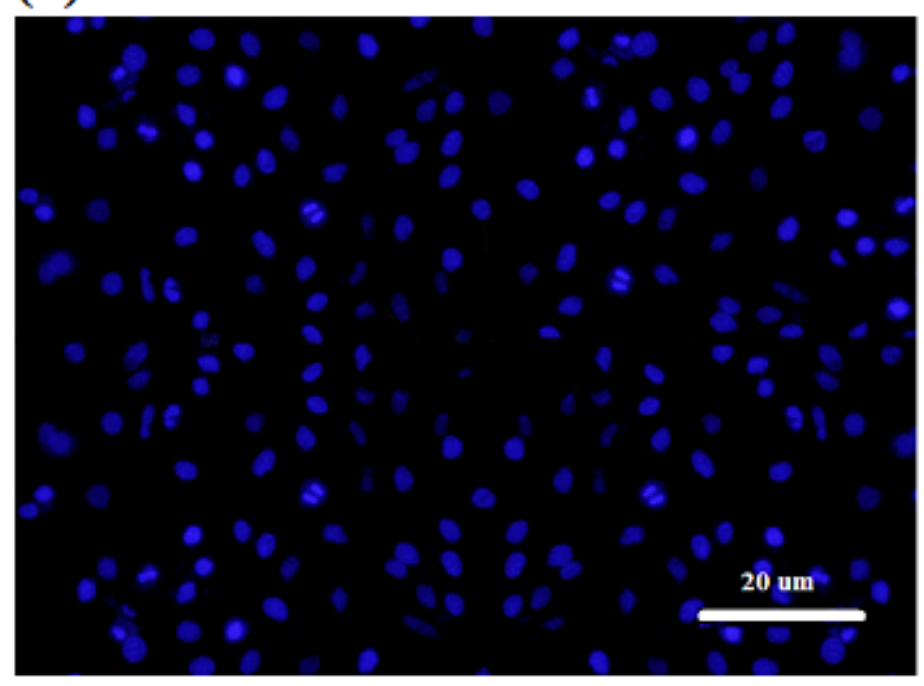

(c)

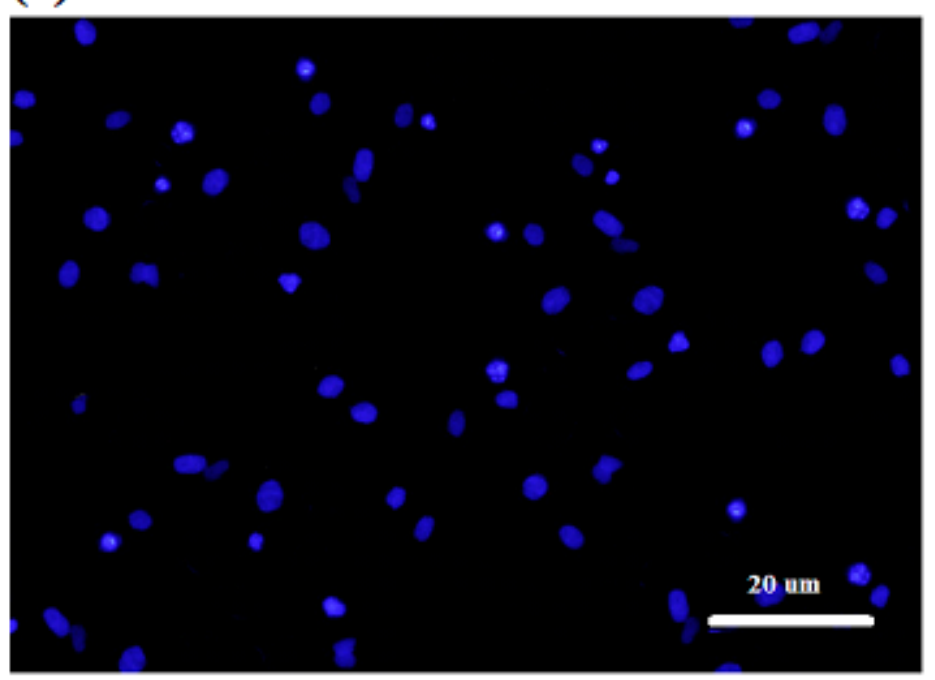

(b)

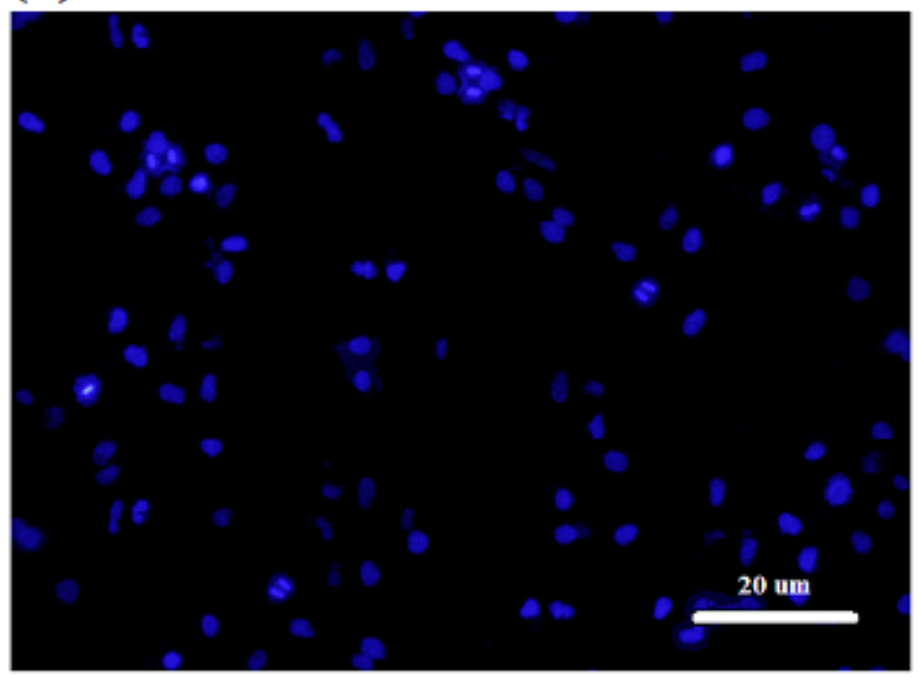

(d)

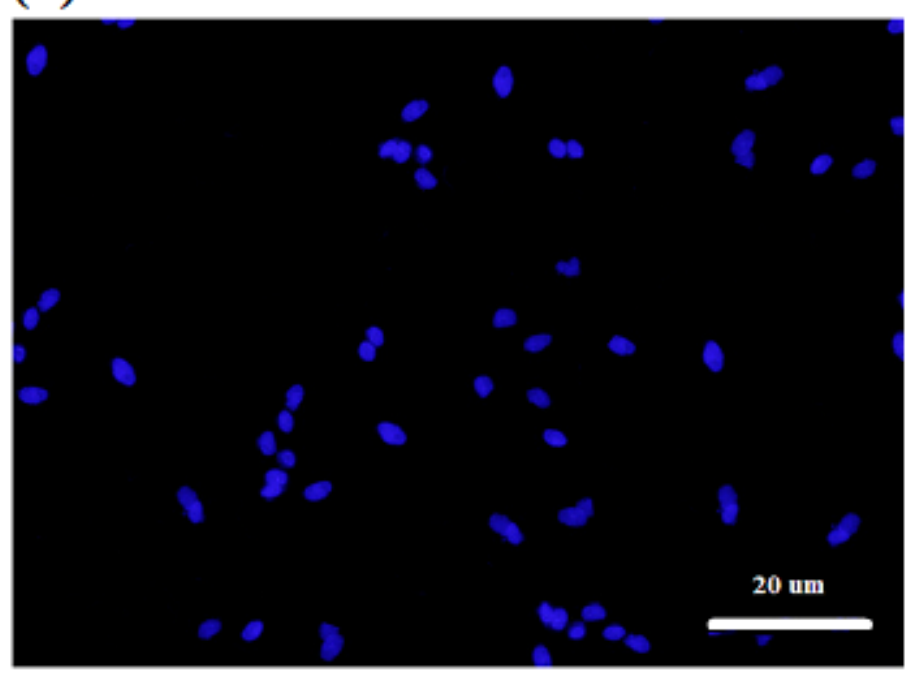

\section{Figure 9}

DAPI staining of (a) A549 cells and A549 cells treated (b) UiO-66-NH2/DOX $100 \mu \mathrm{g} \mathrm{mL-1} \mathrm{NMOFs} \mathrm{and}$ NMOFs coated with (c) $1 \%$ and (d) $2 \%$ PNVCL after $72 \mathrm{~h}$ incubation time 